\title{
CHARACTERIZATION AND CATALYTIC PROPERTY OF MANGANESE(III) COMPLEXES WITH SCHIFF BASES
}

\author{
G.-S. Li, H.-L. Zhang \\ Key Laboratory of Surface \& Interface Science of Henan, School of Material \& Chemical Engineering, Zhengzhou \\ University of Light Industry, Zhengzhou, P. R. China \\ E-mail: gangsen_li@126.com
}

Received June, 19, 2014

Two mononuclear manganese(III) complexes, $\left[\mathrm{MnL}^{1}\left(\mathrm{OH}_{2}\right)\left(\mathrm{CH}_{3} \mathrm{OH}\right)\right] \cdot \mathrm{ClO}_{4}$ (1) and $\left[\mathrm{MnL}^{2}\right]$ (2), where $\mathrm{L}^{1}$ and $\mathrm{L}^{2}$ are the deprotonated forms of $\mathrm{N}, \mathrm{N}^{\prime}$-bis(5-chloro-2-hydroxybenzylidene)ethane-1,2-diamine and tris $\{2-[(3,5$-dichlorosalicylidene $)$ amino $]$ ethyl $\}$ amine, respectively, are obtained by the reaction of Schiff bases with manganese perchlorate in methanol. The complexes were characterized by elemental analysis, IR spectra, and single crystal X-ray determination. In both complexes, $\mathrm{Mn}$ atoms are in the octahedral coordination. In the crystal structure of complex 1, the complex molecules are linked by water ligands through intermolecular $\mathrm{O}-\mathrm{H} \cdots \mathrm{O}$ hydrogen bonds to form dimers. The perchlorate anions are linked to the complex molecules through intermolecular $\mathrm{O}-\mathrm{H} \cdots \mathrm{O}$ hydrogen bonds. In the crystal structure of complex 2 , the molecules are stacked along the $y$ axis through $\pi \cdots \pi$ interactions. The catalytic oxidation on olefins of the complexes is studied.

DOI: $10.15372 / \mathrm{JSC} 20150622$

Ke ywords: manganese complex, mononuclear complex, Schiff base, crystal structure, catalytic oxidation of olefins.

\section{INTRODUCTION}

In recent years, much attention has been paid to explore efficient catalysts for organic reactions [1-5]. A great number of metal complexes have shown interesting catalytic properties for various reactions [ 6-10]. Among the complexes, manganese complexes with Schiff bases are effective catalysts for the aerobic oxidation of olefins [11-13]. Aiming at the exploration of new catalysts for the oxidation of olefins, in the present work, two new mononuclear manganese(III) complexes, $\left[\mathrm{MnL}^{1}\left(\mathrm{OH}_{2}\right)\left(\mathrm{CH}_{3} \mathrm{OH}\right)\right] \cdot \mathrm{ClO}_{4}(\mathbf{1})$ and $\left[\mathrm{MnL}^{2}\right](2)$, where $\mathrm{L}^{1}$ and $\mathrm{L}^{2}$ are the deprotonated forms of $\mathrm{N}, \mathrm{N}^{\prime}-$ bis(5-chloro-2-hydroxybenzylidene)ethane-1,2-diamine $\left(\mathrm{H}_{2} \mathrm{~L}^{1}\right)$ and tris $\{2$-[(3,5-dichlorosalicylidene)amino]ethyl $\}$ amine $\left(\mathrm{H}_{3} \mathrm{~L}^{2}\right)$, respectively, are described.

\section{EXPERIMENTAL}

Materials and measurements. 5-Chlorosalicylaldehyde, 3,5-dichlorosalicylaldehyde, ethylene1,2-diamine and tris(2-aminoethy1)amine were purchased from Fluka and used as received. Manganese perchlorate was prepared by the reaction of manganese carbon in water, followed by recrystallization. The solvents used were of reagent grade. The $\mathrm{H}_{2} \mathrm{~L}^{1}$ and $\mathrm{H}_{3} \mathrm{~L}^{2}$ Schiff bases were prepared according to the literature method [14,15]. Elemental analyses were carried out using a Perkin-Elmer 2400 II elemental analyzer. Infrared spectra were recorded on a Perkin-Elmer FT-IR spectrophoto-

(C) Li G.-S., Zhang H.-L., 2015 
meter with a $\mathrm{KBr}$ disc. GC analyses were carried out using a Shimadzu GC-2014C gas chromatograph. The X-ray diffraction was carried out on a Bruker SMART 1000 CCD area diffractometer at 298(2) K.

Synthesis of $1 . \mathrm{H}_{2} \mathrm{~L}^{1}(3.36 \mathrm{~g}, 0.01 \mathrm{~mol})$ and manganese perchlorate $(3.62 \mathrm{~g}, 0.01 \mathrm{~mol})$ were dissolved and stirred in methanol $(50 \mathrm{ml})$. The mixture was stirred at room temperature for $1 \mathrm{~h}$ and filtered. The filtrate was kept still at room temperature for several days, to give deep brown block-like single crystals. Yield: $45 \%$. Anal. Calcd. for $\mathrm{C}_{17} \mathrm{H}_{18} \mathrm{Cl}_{3} \mathrm{MnN}_{2} \mathrm{O}_{8}$ (\%): C 37.8, H 3.4, N 5.2. Found (\%): C 37.6, H 3.3, N 5.3. IR $\left(\mathrm{KBr}, \mathrm{cm}^{-1}\right): 3423(\mathrm{~m}, \mathrm{O}-\mathrm{H}), 3020-2826(\mathrm{w}, \mathrm{C}-\mathrm{H}$ of aliphatic and aromatic), $1616(\mathrm{~s}, \mathrm{C}=\mathrm{N}), 1560-1500(\mathrm{~s}, \mathrm{C}=\mathrm{C}), 1215(\mathrm{~m}, \mathrm{C}-\mathrm{O}), 1103(\mathrm{~s}, \mathrm{Cl}-\mathrm{O})$.

Synthesis of $2 . \mathrm{H}_{3} \mathrm{~L}^{2}(6.62 \mathrm{~g}, 0.01 \mathrm{~mol})$ and manganese perchlorate $(3.62 \mathrm{~g}, 0.01 \mathrm{~mol})$ were dissolved and stirred in methanol $(50 \mathrm{ml})$. The mixture was stirred at room temperature for $1 \mathrm{~h}$ and filtered. The filtrate was kept still at room temperature for several days, to give deep brown block-like single crystals. Yield: $33 \%$. Anal. Calcd. for $\mathrm{C}_{27} \mathrm{H}_{21} \mathrm{Cl}_{6} \mathrm{MnN}_{4} \mathrm{O}_{3}$ (\%): C 45.2, $\mathrm{H} \mathrm{3.0,} \mathrm{N} \mathrm{7.8.} \mathrm{Found}$ (\%): C 45.4, H 2.8, N 7.8. IR $\left(\mathrm{KBr}, \mathrm{cm}^{-1}\right): 3013-2830$ (w, C-H of aliphatic and aromatic), 1613 (s, $\mathrm{C}=\mathrm{N}), 1560-1500(\mathrm{~s}, \mathrm{C}=\mathrm{C}), 1218(\mathrm{~m}, \mathrm{C}-\mathrm{O})$.

X-ray crystallography. Single crystals of the complexes were mounted on the top of a glass fiber. Graphite monochromatized $\operatorname{Mo} K_{\alpha}$ radiation $(\lambda=0.71073 \AA)$ and the $\omega$ scanning technique were used to collect the diffraction data. Absorption correction was applied with SADABS [16]. The structures of the complexes were solved by a direct method and refined by a full matrix least squares technique using SHELXTL [ 17 ]. Anisotropic thermal parameters were applied to all non-hydrogen atoms.

Crystallographic data for the complexes

\begin{tabular}{|c|c|c|}
\hline Parameter & 1 & 2 \\
\hline Empirical formula & $\mathrm{C}_{17} \mathrm{H}_{18} \mathrm{Cl}_{3} \mathrm{MnN}_{2} \mathrm{O}_{8}$ & $\mathrm{C}_{27} \mathrm{H}_{21} \mathrm{Cl}_{6} \mathrm{MnN}_{4} \mathrm{O}_{3}$ \\
\hline FW & 539.6 & 717.1 \\
\hline Crystal shape / color & Block / brown & Block / brown \\
\hline Crystal size, mm & $0.19 \times 0.17 \times 0.17$ & $0.30 \times 0.26 \times 0.22$ \\
\hline Crystal system & Monoclinic & Triclinic \\
\hline Space group & $P 2_{1} / c$ & $P-1$ \\
\hline$\lambda\left(\mathrm{Mo} K_{\alpha}\right), \AA$ & 0.71073 & 0.71073 \\
\hline$T, \mathrm{~K}$ & $298(2)$ & $298(2)$ \\
\hline$\mu, \mathrm{mm}^{-1}\left(\mathrm{MoK}_{\alpha}\right)$ & 1.032 & 1.008 \\
\hline Unit cell dimensions $a, b, c, \AA$ & $16.049(3), 19.134(3), 14.037(2)$ & $12.901(2), 12.905(2), 20.631(3)$ \\
\hline$\alpha, \beta, \gamma, \operatorname{deg}$ & $\beta 90.177(2)$ & $79.452(2), 73.696(2), 66.409(2)$ \\
\hline$V, \AA^{3}$ & $4310.6(10)$ & $3011.3(6)$ \\
\hline Z & 8 & 4 \\
\hline$T_{\min } / T_{\max }$ & $0.8281 / 0.8441$ & $0.7519 / 0.8087$ \\
\hline No. of measured / unique reflections & 27387 / 7388 & 26644 / 10602 \\
\hline No. of observed reflections $[I \geq 2 \sigma(I)]$ & 4214 & 7383 \\
\hline Data / restraints / parameters & $7388 / 154 / 653$ & $10602 / 0 / 739$ \\
\hline$R_{\text {int }}$ & 0.0835 & 0.0372 \\
\hline$F(000)$ & 2192 & 1448 \\
\hline Goodness of fit on $F^{2}$ & 1.037 & 1.076 \\
\hline$R_{1}, w R_{2}[I \geq 2 \sigma(I)]$ & $0.0942,0.1729$ & $0.0866,0.2126$ \\
\hline$R_{1}, w R_{2}$ (all data) & $0.1610,0.2083$ & $0.1215,0.2318$ \\
\hline Largest / deepest difference hole, e $/ \AA^{-3}$ & $0.460 /-0.433$ & $0.848 /-0.559$ \\
\hline
\end{tabular}


Selected bond lengths $(\AA)$

\begin{tabular}{l|l|l|l||l|l|l|l}
\hline \multicolumn{3}{c||}{} & \multicolumn{5}{|c}{$\mathbf{2}$} \\
$\mathrm{Mn} 1-\mathrm{O} 1$ & $1.878(6)$ & $\mathrm{Mn} 1-\mathrm{O} 2$ & $1.859(6)$ & $\mathrm{Mn} 1-\mathrm{O} 1$ & $2.041(5)$ & $\mathrm{Mn} 1-\mathrm{O} 2$ & $1.889(4)$ \\
$\mathrm{Mn} 1-\mathrm{N} 1$ & $1.950(7)$ & $\mathrm{Mn} 1-\mathrm{N} 2$ & $1.974(7)$ & $\mathrm{Mn} 1-\mathrm{O} 3$ & $1.962(5)$ & $\mathrm{Mn} 1-\mathrm{N} 1$ & $2.053(5)$ \\
$\mathrm{Mn} 1-\mathrm{O} 5$ & $2.290(6)$ & $\mathrm{Mn} 1-\mathrm{O} 6$ & $2.264(7)$ & $\mathrm{Mn} 1-\mathrm{N} 2$ & $2.166(5)$ & $\mathrm{Mn} 1-\mathrm{N} 3$ & $2.275(6)$ \\
$\mathrm{Mn} 2-\mathrm{O} 3$ & $1.878(6)$ & $\mathrm{Mn} 2-\mathrm{O} 4$ & $1.868(6)$ & $\mathrm{Mn} 2-\mathrm{O} 4$ & $2.031(6)$ & $\mathrm{Mn} 2-\mathrm{O} 5$ & $1.890(5)$ \\
$\mathrm{Mn} 2-\mathrm{N} 3$ & $1.977(7)$ & $\mathrm{Mn} 2-\mathrm{N} 4$ & $1.966(7)$ & $\mathrm{Mn} 2-\mathrm{O} 6$ & $1.960(6)$ & $\mathrm{Mn} 2-\mathrm{N} 5$ & $2.164(7)$ \\
$\mathrm{Mn} 2-\mathrm{O} 7$ & $2.291(6)$ & $\mathrm{Mn} 2-\mathrm{O} 8$ & $2.251(7)$ & $\mathrm{Mn} 2-\mathrm{N} 6$ & $2.257(7)$ & $\mathrm{Mn} 2-\mathrm{N} 7$ & $2.060(6)$
\end{tabular}

T a b 1 e 3

\begin{tabular}{|c|c|c|c|c|}
\hline$D-\mathrm{H} \cdots A$ & $D-\mathrm{H}$ & $\mathrm{H} \cdots A$ & $D \cdots A$ & $D-\mathrm{H} \cdots A$ \\
\hline $\mathrm{O} 7-\mathrm{H} 7 \mathrm{~A} \cdots \mathrm{O} 3^{\mathrm{i}}$ & $0.85(1)$ & $1.97(2)$ & $2.816(9)$ & $172(10)$ \\
\hline $\mathrm{O} 7-\mathrm{H} 7 \mathrm{~A} \cdots \mathrm{O} 4^{\mathrm{i}}$ & $0.85(1)$ & $2.65(9)$ & $3.129(9)$ & $117(8)$ \\
\hline $\mathrm{O} 8-\mathrm{H} 8 \cdots \mathrm{O} 9$ & $0.85(1)$ & $1.97(7)$ & $2.69(2)$ & $142(10)$ \\
\hline
\end{tabular}

Symmetry codes: ${ }^{\mathrm{i}} 1-x,-y, 1-z$.

The hydrogen atoms of the water and methanol molecules were located from electron density maps, with $\mathrm{O}-\mathrm{H}$ and $\mathrm{H} \cdots \mathrm{H}$ distances restrained to $0.85(1) \AA$ and $1.37(2) \AA$, respectively. The other hydrogen atoms were generated geometrically. The perchlorate anions in complex 1 are disordered, with occupancies of 0.323(2) and 0.677(2) for the $\mathrm{Cl1}-\mathrm{O} 9-\mathrm{O} 10-\mathrm{O} 11-\mathrm{O} 12$ group, and 0.766(2) and $0.234(2)$ for the $\mathrm{Cl} 2-\mathrm{O} 13-\mathrm{O} 14-\mathrm{O} 15-\mathrm{O} 16$ group. The crystallographic data and details of the data collection and refinement for the complex are listed in Table 1. Selected bond lengths and angles are given in Table 2. Hydrogen bonding information is given in Table 3. Crystallographic data for the complexes have been deposited with the Cambridge Crystallographic Data Centre (CCDC 1008303 and 1008304).

Catalytic epoxidation of olefins. To a solution of olefins $(0.28 \mathrm{mmol}), \mathrm{NaHCO}_{3}(0.11 \mathrm{mmol})$ and catalyst $\left(9.4 \times 10^{-4} \mathrm{mmol}\right)$ in $\mathrm{MeCN}(0.5 \mathrm{ml}) \mathrm{H}_{2} \mathrm{O}_{2}\left(1.1 \mathrm{mmol}, 30 \% \mathrm{H}_{2} \mathrm{O}\right.$ solution $)$ was added as an oxidant. After the reaction was over, for the products analysis the solution was subjected to multiple ether extraction, and the extract was also concentrated down to $0.5 \mathrm{~cm}^{3}$ by distillation in a rotary evaporator at room temperature; then a sample $(2 \mu \mathrm{L})$ was taken from the solution and analyzed by GC. The retention times of the peaks were compared with those of the commercial standards, and chlorobenzene was used as the internal standard for the GC yield calculation.

\section{RESULTS AND DISCUSSION}

Synthesis. The two complexes were readily prepared by the reaction of equimolar quantities of the Schiff base ligands with manganese perchlorate in methanol. It should be noted that even though no problem occurred, perchlorate salts are potentially explosive. Only small quantities of such chemicals should be handled and with great care. Elemental analyses of the complex are in good agreement with the expected values.

Infrared spectra of the complexes. The medium and broad absorption centered at $3423 \mathrm{~cm}^{-1}$ for 1 can be assigned to the $\mathrm{O}-\mathrm{H}$ stretching vibrations of water and methanol ligands. Weak absorptions in the $3010-2820 \mathrm{~cm}^{-1}$ region result from $\mathrm{C}-\mathrm{H}$ vibrations of the aliphatic and aromatic groups. Intense absorptions at $1616 \mathrm{~cm}^{-1}$ for $\mathbf{1}$ and $1613 \mathrm{~cm}^{-1}$ for 2 can be assigned to the vibration of $\mathrm{C}=\mathrm{N}$ groups. The intense absorption indicative of the perchlorate anion is observed at $1103 \mathrm{~cm}^{-1}$. 


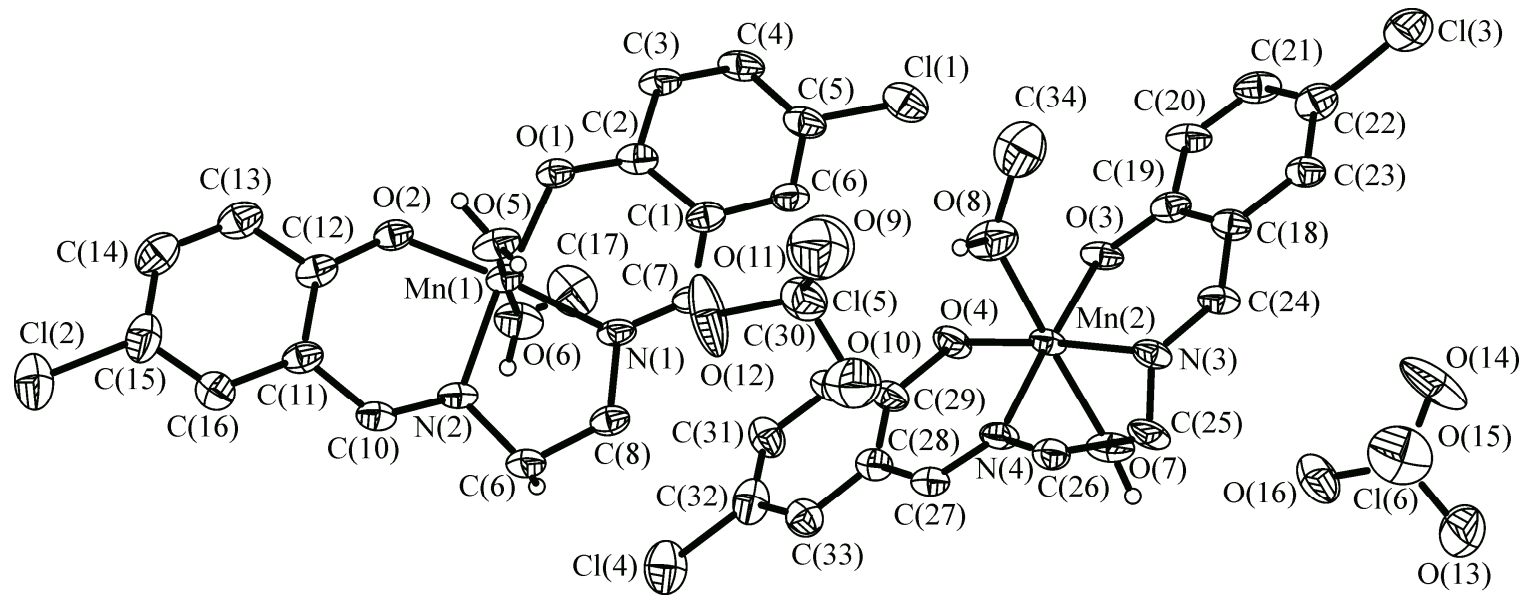

Fig. 1. Molecular structure of complex $\mathbf{1}$ at a $30 \%$ probability level

Structure description of $\mathbf{1}$. The molecular structure of complex $\mathbf{1}$ is shown in Fig. 1. The asymmetric unit of the complex contains two mononuclear manganese(III) complex cations and two perchlorate anions. The Mn atoms in the complex cations are in the octahedral coordination, with two imino $\mathrm{N}$ and two phenolate $\mathrm{O}$ atoms defining the equatorial plane, and with one water $\mathrm{O}$ and one methanol $\mathrm{O}$ atoms located at the axial positions. The axial bonds are obviously longer than the equatorial ones, which is caused by Jahn-Teller effects. The distortion of the coordination can be observed from the bond angles related to the $\mathrm{Mn}$ atoms. Due to the strain from the five-membered chelated Mn1$\mathrm{N} 1-\mathrm{C} 8-\mathrm{C} 9-\mathrm{N} 2$ and $\mathrm{Mn} 2-\mathrm{N} 3-\mathrm{C} 25-\mathrm{C} 26-\mathrm{N} 4$ rings, the $\mathrm{N} 1-\mathrm{Mn} 1-\mathrm{N} 2$ and $\mathrm{N} 3-\mathrm{Mn} 2-\mathrm{N} 4$ angles are much small. The $\mathrm{Mn}-\mathrm{O}$ and $\mathrm{Mn}-\mathrm{N}$ bond lengths in the present complex are comparable to those observed in similar manganese complexes [18,19]. The dihedral angles between the two benzene rings of the Schiff base ligands are 5.6(3) ${ }^{\circ}$ for the Mn1 molecule and 5.0(3) ${ }^{\circ}$ for the $\mathrm{Mn} 2 \mathrm{mo}-$ lecule. In the crystal structure of the complex (Fig. 2) the perchlorate anions are linked to the complex

Fig. 2. Molecular packing of complex 1, viewed along the $y$ axis. Hydrogen bonds are shown as dashed lines

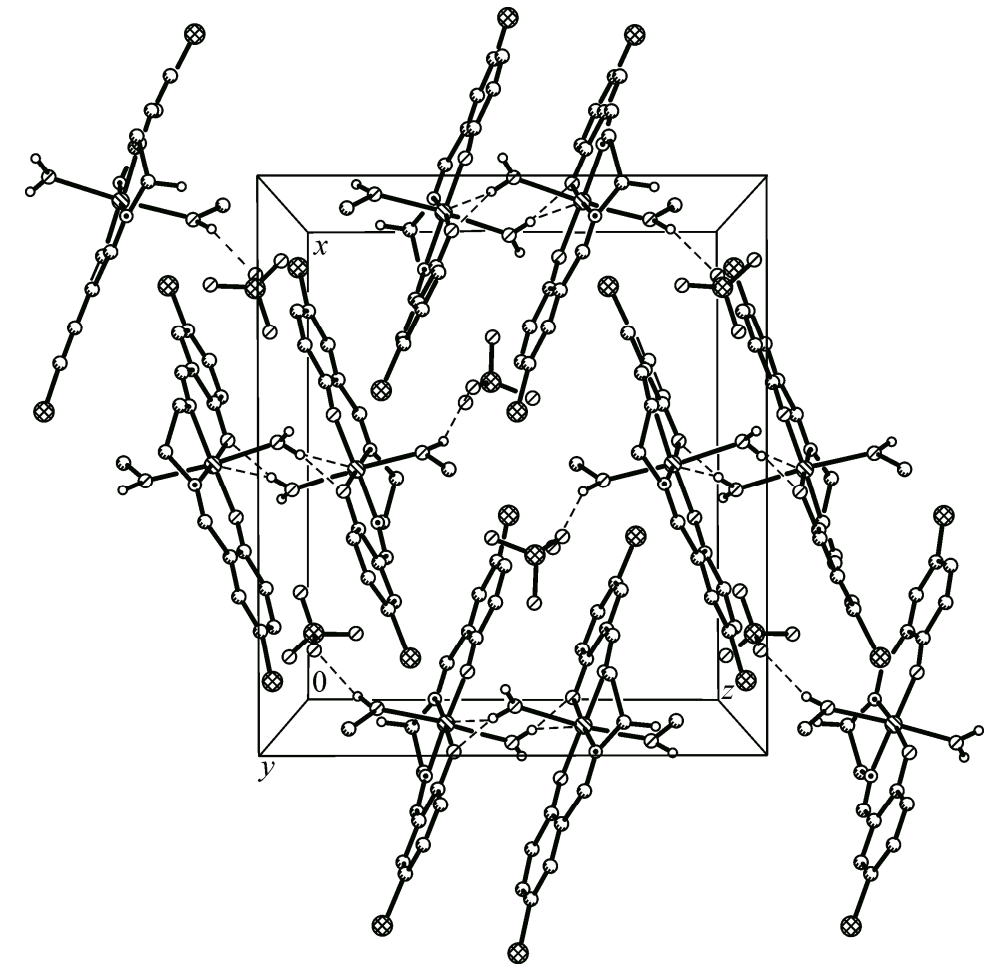


Parameters between the planes for $\mathbf{1}$

\begin{tabular}{c|c|c|c|c}
\hline$C g$ & $\begin{array}{c}\text { Distance between } \\
\text { ring centroids, } \AA\end{array}$ & $\begin{array}{c}\text { Dihedral } \\
\text { angle, deg. }\end{array}$ & $\begin{array}{c}\text { Perpendicular distance } \\
\text { of } C g(\mathrm{I}) \text { on } C g(\mathrm{~J}), \AA\end{array}$ & $\begin{array}{c}\text { Perpendicular distance } \\
\text { of } C g(\mathrm{~J}) \text { on } C g(\mathrm{I}), \AA\end{array}$ \\
\hline$C g(1)-C g(2)^{\mathrm{ii}}$ & 4.982 & 4 & -3.182 & -3.411 \\
$C g(1)-C g(4)^{\mathrm{ii}}$ & 4.702 & 2 & -3.300 & -3.305 \\
$C g(2)-C g(3)^{\mathrm{ii}}$ & 4.896 & 7 & -3.344 & -3.408 \\
$C g(3)-C g(4)^{\mathrm{ii}}$ & 3.730 & 5 & -3.424 & -3.456 \\
$C g(4)-C g(5)^{\mathrm{ii}}$ & 4.788 & 48 & 2.183 & 4.622 \\
$C g(5)-C g(6)^{\mathrm{iii}}$ & 4.981 & 3 & -3.206 & -3.398 \\
$C g(5)-C g(8)^{\mathrm{iii}}$ & 4.700 & 2 & -3.291 & -3.314 \\
$C g(6)-C g(7)^{\mathrm{iii}}$ & 4.902 & 7 & -3.348 & -3.426 \\
$C g(7)-C g(8)^{\mathrm{iii}}$ & 3.739 & 5 & -3.427 & -3.465 \\
$C g(8)-C g(1)^{\mathrm{iv}}$ & 4.766 & 48 & 2.188 & 4.605
\end{tabular}

Symmetry codes: ${ }^{\text {ii }}-x, 1-y, 1-z$; ${ }^{\text {iii }} 1-x, 1-y,-z$; ${ }^{\text {iv }} 1-x, 1-y, 1-z$.

$C g(1), C g(2), C g(3), C g(4), C g(5), C g(6), C g(7)$, and $C g(8)$ are the centroids of Mn1-O1$\mathrm{C} 2-\mathrm{C} 1-\mathrm{C} 7-\mathrm{N} 1, \mathrm{Mn} 1-\mathrm{O} 2-\mathrm{C} 12-\mathrm{C} 11-\mathrm{C} 10-\mathrm{N} 2, \mathrm{C} 1-\mathrm{C} 2-\mathrm{C} 3-\mathrm{C} 4-\mathrm{C} 5-\mathrm{C} 6, \mathrm{C} 11-$ $\mathrm{C} 12-\mathrm{C} 13-\mathrm{C} 14-\mathrm{C} 15-\mathrm{C} 16, \mathrm{Mn} 2-\mathrm{O} 3-\mathrm{C} 19-\mathrm{C} 18-\mathrm{C} 24-\mathrm{N} 3, \mathrm{Mn} 2-\mathrm{O} 4-\mathrm{C} 29-\mathrm{C} 28-$ $\mathrm{C} 27-\mathrm{N} 4, \mathrm{C} 18-\mathrm{C} 19-\mathrm{C} 20-\mathrm{C} 21-\mathrm{C} 22-\mathrm{C} 23$, and $\mathrm{C} 28-\mathrm{C} 29-\mathrm{C} 30-\mathrm{C} 31-\mathrm{C} 32-\mathrm{C} 33$, respectively.

cations through intermolecular $\mathrm{O}-\mathrm{H} \cdots \mathrm{O}$ hydrogen bonds (Table 3). The crystal structure is stabilized by intermolecular $\mathrm{O}-\mathrm{H} \cdots \mathrm{O}$ hydrogen bonds and $\pi \cdots \pi$ interactions (Table 4 ).

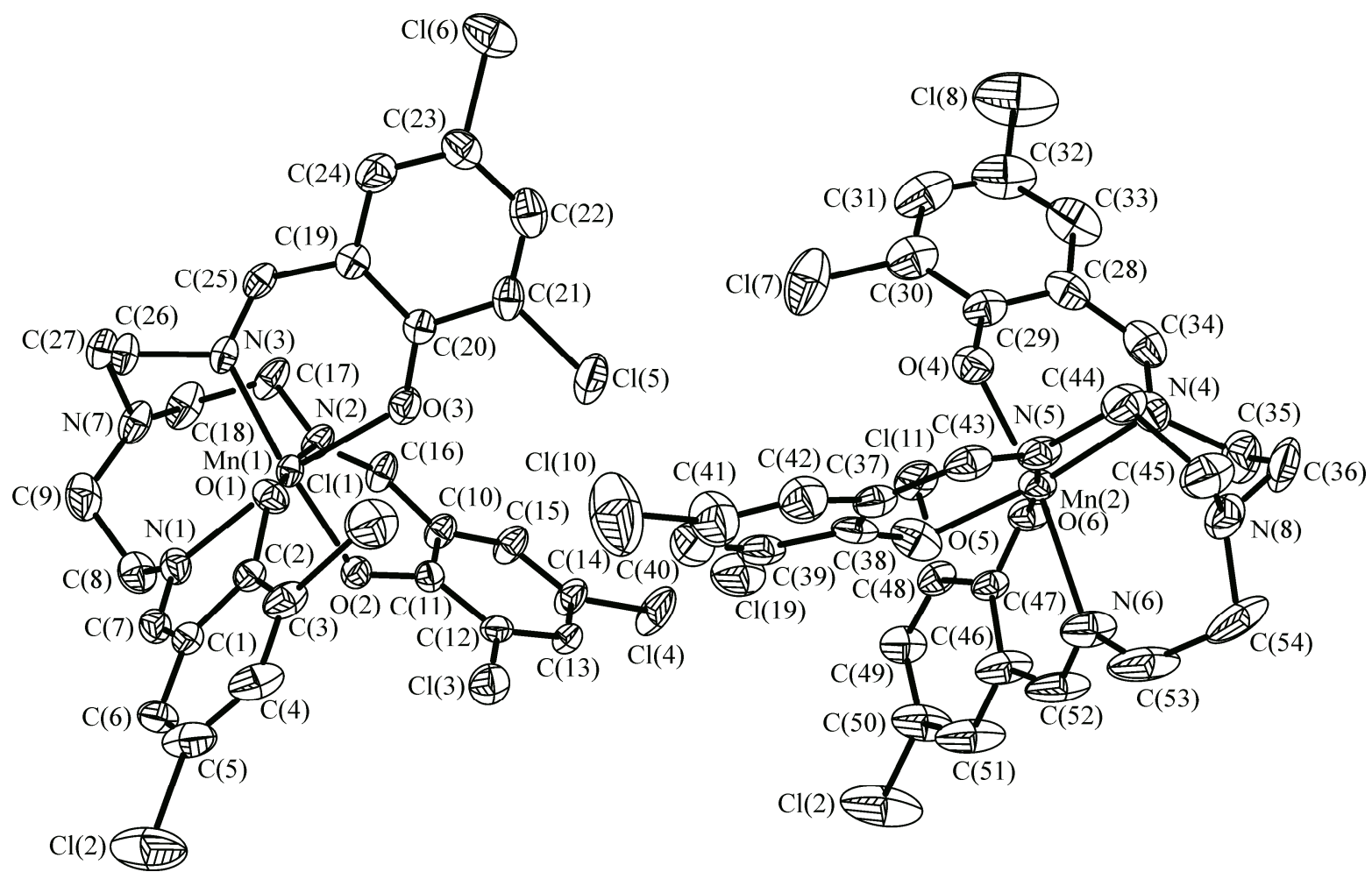

Fig. 3. Molecular structure of complex 2 at a $30 \%$ probability level 
T a b l e 5

Catalytic oxidation results ${ }^{1}$

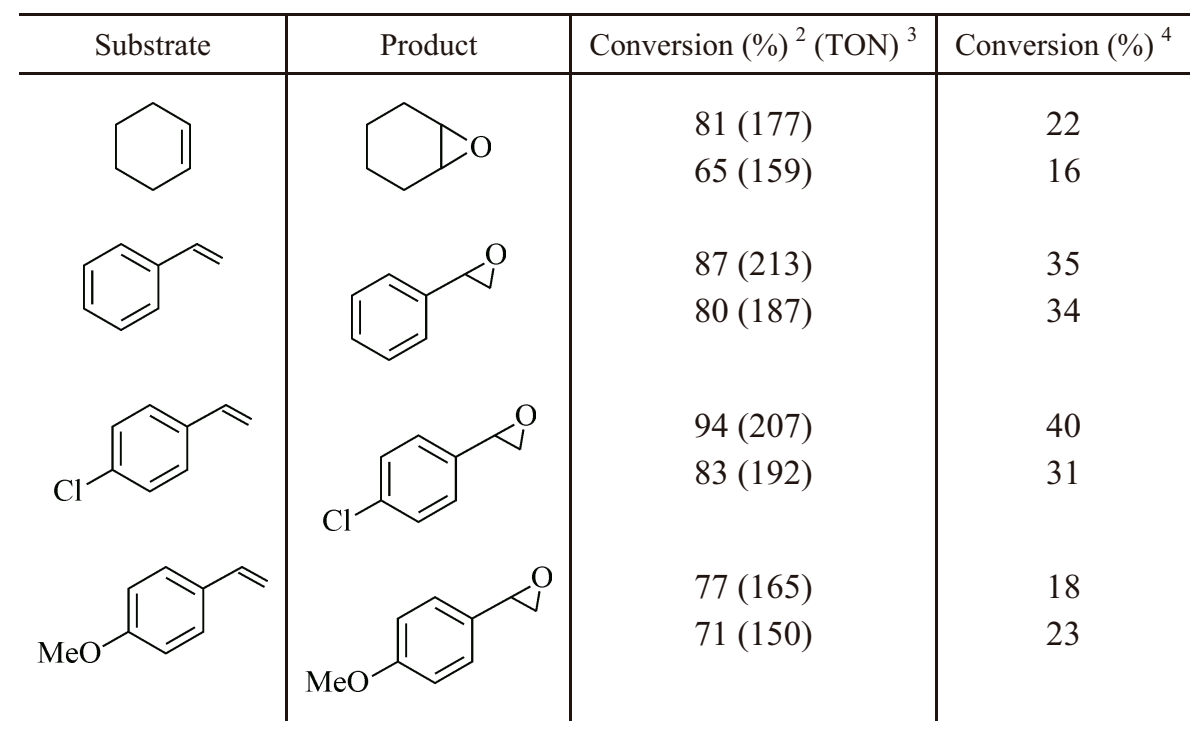

\footnotetext{
${ }^{1}$ Molar ratios for the catalyst: substrate: $\mathrm{NaHCO}_{3}: \mathrm{H}_{2} \mathrm{O}_{2}$ are 1:300:120:1200. The reactions were performed in a (80:20) mixture of $\mathrm{CH}_{3} \mathrm{OH} / \mathrm{CH}_{2} \mathrm{Cl}_{2}$ under ambient conditions.

${ }^{2}$ The GC conversion was measured relative to starting olefin after $75 \mathrm{~min}$.

${ }^{3} \mathrm{TON}=(\mathrm{mmol}$ of product $) / \mathrm{mmol}$ of catalyst.

${ }^{4}$ Conversion without the addition of sodium bicarbonate.
}

Structure description of 2. The molecular structure of complex $\mathbf{2}$ is shown in Fig. 3. The asymmetric unit of the complex contains two mononuclear manganese(III) complex molecules. The Mn atoms in the complex molecules are in the octahedral coordination, with two imino $\mathrm{N}$ and two phenolate $\mathrm{O}$ atoms defining the equatorial plane, and with one imino $\mathrm{N}$ and one phenolate $\mathrm{O}$ atoms located at the axial positions. The distortion of the coordination can be observed from the bond angles related to the $\mathrm{Mn}$ atoms. The cis and trans angles range from $82.1(2)^{\circ}$ to $101.6(2)^{\circ}$, and $168.9(2)^{\circ}$ to $175.9(2)^{\circ}$ for $\mathrm{Mn} 1$, and from $80.9(2)^{\circ}$ to $104.4(3)^{\circ}$, and $165.6(3)^{\circ}$ to $176.7(3)^{\circ}$ for $\mathrm{Mn} 2$. The $\mathrm{Mn}-\mathrm{O}$ and $\mathrm{Mn}-\mathrm{N}$ bond lengths in the present complex are comparable to those observed in similar manganese complexes [20-22 ]. The dihedral angles among the benzene rings of the Schiff base ligands are $72.7(3)^{\circ}, 79.8(3)^{\circ}$, and $67.9(3)^{\circ}$ for the Mn1 molecule, and $68.8(3)^{\circ}, 86.3(3)^{\circ}$, and $68.5(3)^{\circ}$ for the Mn2 molecule. The apical N7 and N8 nitrogen atoms are not involved in the coordination and have long distances to the metal atoms in the range 3.07-3.20 $\mathrm{A}$. The angles of the apical atoms to the neighboring carbon atoms are forced to $115-120^{\circ}$, thus strongly deviating from an aminic trigonal pyramid. It is considered that the apical $\mathrm{N}$ atoms are repelled by the metal atoms.

Catalytic properties. The catalytic oxidation results are listed in Table 5.The complexes have good catalytic capability in the oxidation of selected olefins to the corresponding epoxides. It is clear that complex 1 shows a slightly better activity than complex $\mathbf{2}$, which might be induced by the weak coordination of the water and methanol molecules at the axial positions. When $\mathrm{H}_{2} \mathrm{O}_{2}$ was used as a sole oxidant the catalytic efficiency was not good, but when $\mathrm{NaHCO}_{3}$ was added as a co-catalyst the efficiency of the system increased sharply. $\mathrm{H}_{2} \mathrm{O}_{2}$ and hydrogen carbonate may react in an equilibrium process to produce peroxymonocarbonate, $\mathrm{HCO}_{4}^{-}$, which is a more reactive nucleophile than $\mathrm{H}_{2} \mathrm{O}_{2}$ and speeds up the epoxidation reaction. 


\section{REFERENCES}

1. Amini M., Haghdoost M.M., Bagherzadeh M. // Coord. Chem. Rev. - 2014. - 268. - P. 83 - 100 .

2. Wang F., Lu C.-H., Willner I. // Chem. Rev. - 2014. - 114, N 5. - P. $2881-2941$.

3. Martins L.M.D.R.S., Pombeiro A.J.L. // Coord. Chem. Rev. - 2014. - 265. - P. 74 - 88.

4. Arevalo A., Tlahuext-Aca A., Flores-Alamo M., Garcia J.J. // J. Am. Chem. Soc. - 2014. - 136, N 12. - P. $4634-4639$.

5. Haldon E., Delgado-Rebollo M., Prieto A., Alvarez E., Maya C., Nicasio M.C., Perez P.J. // Inorg. Chem. - 2014. - 53, N 8. - P. $4192-4201$.

6. Lei Y., Yang Q.-W., Chen G.-C., Yang Q.-L. // Synth. React. Inorg., Met. - Org., Nano - Met. Chem. - 2014. - 44, N 4. - P. 590 - 597.

7. Mobinikhaledi A., Zendehdel M., Safari P. // Transition Met. Chem. - 2014. - 39, N 4. - P. $431-442$.

8. Feng Y.-X., Xue L.-W., Zhang C.-X. // Russ. J. Coord. Chem. - 2014. - 40, N 5. - P. 337 - 341.

9. Shit S., Saha D., Saha D., Row T.N.G., Rizzoli C. // Inorg. Chim. Acta. - 2014. - 415. - P. $103-110$.

10. McGuirk C.M., Stern C.L., Mirkin C.A. // J. Am. Chem. Soc. - 2014. - 136, N 12. - P. $4689-4696$.

11. Durak D., Delikanli A., Demetgul C., Kani I., Serin S. // Transition Met. Chem. - 2013. - 38, N 2. - P. 199 206.

12. Salavati-Niassari M., Davar F., Bazarganipour M. // Dalton Trans. - 2010. - 39, N 31. - P. 7330 - 7337.

13. Louloudi M., Nastopoulos V., Gourbatsis S., Perlepes S.P., Hadjiliadis N. // Inorg. Chem. Commun. - 1999. - 2, N 10. - P. $479-483$.

14. Kubono K., Kazumasa K., Yokoi K. // Acta Crystallogr. - 2004. - E60, N 8. - P. o1383/o1384.

15. Kanesato M., Ngassapa F.N., Yokoyama T. // Anal. Sci. - 2000. - 16, N 7. - P. 781/782.

16. Sheldrick G.M. SADABS Program for Empirical Absorption Correction of Area Detector, University of Göttingen, Germany, 1996.

17. Sheldrick G.M. SHELXTL, Version 6.10, Software Reference Manual, Bruker Instrumentation, Madison, Wisconsin, USA, 2000.

18. Aurangzeb N., Hulme C.E., McAuliffe C.A., Pritchard R.G., Watkinson M., Bermejo M.R., Garcia-Deibe A., Rey M., Sanmartin J., Sousa A. // Chem. Commun. - 1994. - N 9. - P. 1153 - 1156.

19. Bermejo M.R., Castineiras A., Garcia-Monteagudo J.C., Rey M., Sousa A., Watkinson M., McAuliffe C.A., Pritchard R.G., Beddoes R.L. // J. Chem. Soc., Dalton Trans. - 1996. - N 14. - P. 2935 - 2944.

20. Alcock N.W., Cook D.F., McKenzie E.D., Worthington J.M. // Inorg. Chim. Acta. - 1980. - 38, N 1. - P. 107 112.

21. Chandra S.K., Chakravorty A. // Inorg. Chem. - 1991. - 30, N 20. - P. 3795 - 3796.

22. Schramm A., Stroh C., Dossel K., Lukas M., Fischer M., Schramm F., Fuhr O., Lohneysen H.V., Mayor M. // Eur. J. Inorg. Chem. - 2013. - N 1. - P. 70 - 79. 